Engine Research and Development at the Ministry
of Aviation:
Dr. John Remfry

Dr. JoHN REMFry has been appointed director of engine research and development at the Ministry of Aviation, in succession to Dr. J. W. Drinkwater, who is now at the National Gas Turbine Establishment, Farn. borough. Born in 1904, he held a Foundation Scholarship at Sir Joseph Williamson's Mathematical School, Rochestrex, before entoring H.M. Dockyard, Dovonport, as an indenturod apprentice to Marine Engineering and Shipbuilding in 1919, whero he gained the Admiralty Prize for first place in school subjects in all dockyards in 192: and a Whitworth scholarship in 1924. He graduated with the degreo of B.Se.(Eng.) with honours in mechanical engineoring and motivo power at the City and Guilds Engineering Colloge in the University of London in 1926 and was awarded the Diploma of the Imperial College in acronauties in 1927 aftor post-graduate study at the Royal College of Science. After a year at the National Physical Laboratory, Dr. Rernfry was until 1936 a research engineer with Messrs. Rowntree and Co., York. During the next year in the Chief Engineer's Department of the London County Council he was concerned with the? efficient generation and utilization of steam and electrical power. In 1937 he joined the Engine Department of the Royal Aircraft Establishment, Farnborough, and worked on problems of heat interchange for aircraft engine radiators, oil coolers and charge coolers. In 1944 he was transferred to the Directorate of Engine Research and Development, which was successively under the Ministries of Aireraft Production, Supply and Aviation, where he was engaged on tho performanee estimation and approval of reciprocating and gas turbine engines and the supervision of research at universities and contractors works on aerodynamies, thermodynamics, hoat transfor and engine materials. $\mathrm{He}$ has been an assistant director for acro engine projects and performance since 1950.

\section{International Academy of Astronautics: Honorary Members}

Prince Louis de Broglie, Miss Jacqueline Cochran and Mr. Harry F. Guggenheim have been elected honorary members of the International Academy of Astronautics. The first honorary member of the Academy was the late Prof. Niels Bohr.

Prince Louis do Broglie, the well-known French physicist, has made major contributions to the development of modern physics and to the fostering of international scientific co-oporation. Ho is a member of the French Academy of Sciences and has beon its secretary since 1942. Prince Louis de Broglie has received many honours and awards, including the Nobel Prizo for Physies in 1929. For his efforts to explain aspects of modern physies to the layman, he was the first recipient of the Uneseo Kalinga Prize in 1953. Ho has been professor at the Institut Henri Poincaré in Paris since 1928, and in 1943 he founded a Centre for Studies in Applied Mathematies. In 1945 ho was counsellor to the French High Commission on Atomic Energy.

Miss Jacqueline Cochran (Mrs. Floyd B. Odlum), the leading woman in American aviation, has done much to prove that womon are as capable as men to achiove sucess in the field of practical flying. Sho was the first woman to fly in the Bendix transcontinental raco in 1934. and has since won numerous Bendix trophies, as woll as the Clifford Burke Harmon Trophy of the Intornational League of Aviators. Miss Cochran was the first woman pilot to pierce the sonic barrier in 1953, and she holds several national and intornational flight rocords. Since 1959 she has been president of the International Aero. nautical Federation, an organization the functions of which now include the verification and maintenance of manned space flight, records.
Mr. Harry F. Guggenhoim, American philanthropist and publisher, has played an important part in the promotion of aeronautics and astronauties both on a national scale and on an international level. His interest in aviation goes back to the 1920's. He was U.S. dolegate to the International Conferences on Civil Aeronauties in Washington, D.C., in 1927 and 1928. As president of the Daniel and Florence Guggenhoim Foundation, he founded the Daniol and Florence Guggenheim Jet Propulsion Centres at Princeton Univorsity and at the California Institute of Technology, where his father had previously founded the Guggenheim Aeronantical Laboratory. Mr. Guggenheim was U.S. Ambassador to Cuba during 1929 33 , and ho has been honoured with numerous awards and docorations.

\section{Anglo-Belgian Company for Marine Reactor Develop- ment}

The United Kingdom Atomic Energy Authority and a syndicate of Belgian industrial companies hoaded by Belgonucléaire havo jointly formed a company to own all the results of their development programme for the Vulcain reactor. The formation of the Company follows an announcoment in May 1962 that the Authority had signed an agreement with Belgonucléaire to undertako a joint rosearch and dovelopment programme on a design of nuclear reactor suitable for marine propulsion-given the name of Vulcain-on which Belgonucléaire had already done much preliminary work. This reactor is an advanced version of the pressurized water reactor embodying the principlo of variable moderation. The Authority's participation in this joint effort is part of the programmo of research announced by the Ministor of Transport in Novembor 1961 to develop a reactor system economically attractive to a wide range of shipping. This research is being undertaken with tho approval and support of the Working Group on Marine Reactor Research, appointed jointly by the Minister for Science and the Minister of Transport. After assessing the relative merits of a number of reactor types most suitable for further development for marine propulsion, the Working Group's recommendation was accepted in November 1962, that the programme of research be concontrated in future on two types. One of these is the Vulcain reactor, and the other is the Integral Boiling Reactor, which is an advanced reactor concept originating within the Authority.

\section{Fuel Elements for Scorpio Reactor}

The Metallurgy Division at Harwoll has recently com pleted the production of 400 plutonium-bearing fuel elements for Scorpio (Sub-critical carbon-moderated reactor assembly for plutonium investigations) oxperiments at the Atomic Energy Establishment, Winfrith. They are being used to simulate the partially used uranium fuel elements of a power reactor, in which plutonium has been formed by neutron bombardment of uranium-238; this plutonium build-up profoundly affects the behaviour of a reactor, especially its response to temperature variations. The fuel elements take the form of eylindrical bars, $28 \mathrm{in}$. long by $1.2 \mathrm{in}$. diameter, of depleted uranium entaining 0.43 por cent uranium-235 with 0.25 per cent plutonium added; they are sheathod in stainless steel 0.015 in. thick. It is hoped that tho Scorpio oxperiments will not only improvo the basic understanding of plutonium reactor physics but will also help to check the accuracy of theorotical ealculations of the effects of plutonium buildup in power reactors. The Scorpio's are sub-critical graphite-modorated reactor assemblies of widely variable lattice geometries and capable of being heated to temperatures of up to $400^{\circ} \mathrm{C}$. Precise measurements of noutron flux distribution throughout such an assombly (in Scorpio 1), or within individual lattice colls (in Scorpio 2), enable the reactivity of a system to be studied at, different temperatures. 